\title{
Kajian Pengawasan Peredaran Obat Keras di Sumatera Barat oleh BBPOM di Padang
}

(Study on controlling of prescription drugs circulation in West Sumatera by provincial NADFC in Padang)

\author{
Firdaus Thantawi*, Erizal \& Elfi Sahlan Ben
}

Fakultas Farmasi Universitas Andalas, Limau Manis, Kecamatan Pauh, Kota Padang, Sumatera Barat

\begin{abstract}
The phenomenon of the high circulation of hard drugs in unauthorized facilities is caused by the high demand of the community, the low price and the low level of public knowledge and awareness. This study aims to control the performance of BBPOM in Padang, the level of success in law enforcement and increased public awareness. The research is evaluative with a triangulation approach. There were 70 questionnaire respondents from 7 districts in West Sumatera and 10 structured interview respondents from BBPOM officials in Padang and Jayapura. A total of 5 types of questionnaire were validated with a reliability value of $0.8427 ; 0.8507 ; 0.7493 ; 0.7399$ and 0.8272 . The results showed that there was a trend of increasing circulation of prescription drugs in drug stores by $24 \% ; 45 \%$ and $49 \%$ while in supermarkets there was a decrease of $17 \% ; 17 \%$ and $8 \%$. Law enforcement in the drug sector has increased by $33.3 \% ; 70.0 \%$ and a decrease of $18.2 \%$. Consumer empowerment through increased understanding of prescription drugs (92.9\% and 100.0\%). In conclusion, the performance of BBPOM in Padang still needs to be optimized with a strategy of routine monitoring, consumer empowerment, law enforcement and synergy with related stakeholders.
\end{abstract}

Keywords: prescription drugs; controlling; provincial NADFC in Padang; triangulation.

ABSTRAK: Fenomena tingginya peredaran obat keras di sarana yang tidak berwenang disebabkan karena tingginya kebutuhan masyarakat, harganya yang murah serta masih rendahnya pengetahuan dan kesadaran masyarakat. Penelitian ini bertujuan untuk mengawasi kinerja BBPOM di Padang, tingkat keberhasilan penegakan hukum dan tingkat keberhasilan peningkatan kesadaran masyarakat. Penelitian bersifat evaluatif dengan pendekatan triangulasi. Responden kuesioner berjumlah 70 orang yang berasal dari 7 kabupaten/kota di Sumatera Barat. Responden wawancara terstruktur sejumlah 10 orang yang berasal dari pejabat struktural BBPOM di Padang dan Jayapura. Sebanyak 5 jenis kuesioner divalidasi dengan nilai reliabilitas 0.8427; 0.8507; 0.7493; 0.7399 dan 0.8272 . Hasil penelitian menunjukkan bahwa terjadi trend peningkatan peredaran obat keras di TOB sebesar 24\%; $45 \%$ dan $49 \%$, sedang di swalayan terjadi penurunan sebesar $17 \%, 17 \%$ dan $8 \%$. Penegakan hukum di bidang obat terjadi peningkatan sebesar 33.3\%; 70.0\% dan penurunan 18.2\%. Pemberdayaan konsumen melalui peningkatan pemahaman obat keras $(92.9 \%$ dan 100.0\%). Kesimpulan penelitian ini adalah kinerja BBPOM di Padang masih perlu dioptimalkan dengan strategi pengawasan rutin, pemberdayaan konsumen, penegakan hukum dan sinergitas dengan stakeholder terkait.

Kata kunci: obat keras; pengawasan; BBPOM Padang; triangulasi.

\section{Pendahuluan}

Kemajuan di bidang teknologi dan transportasi menyebabkan produk farmasi dengan cepat menyebar [1]. Tingginya kebutuhan obat keras oleh masyarakat, murahnya harga obat di sarana tidak berwenang, masih rendahnya pengetahuan dan kesadaran masyarakat akan keamanan, kemanfaat dan mutu obat yang disediakan sarana yang berwenang mengakibatkan fenomena tingginya peredaran obat keras di sarana yang tidak berwenang [2,3].

Obat merupakan produk farmasi dan salah satu unsur terpenting dalam pelayanan kesehatan [4]. Rasionalitas penggunaan obat dikenal dengan tepat indikasi, tepat dosis, tepat waktu dan tepat biaya [5,6]. Penggolongan obat dilakukan untuk meningkatkan keamanan dan distribusinya [7]. Obat dibedakan atas obat bebas, obat bebas terbatas, obat keras dan psikotropik narkotik [8-11].

Obat keras hanya dapat diperoleh di apotik dengan resep dokter dan diserahkan oleh apoteker [12,13]. Fenomena peredaran obat keras di sarana tidak berwenang masih marak terjadi [14-16]. Pengawasan dilakukan untuk meminimalkan penyimpangan [17] dan mendeteksi sebab penyimpangan [18].

Dalam hal pengawasan di bidang obat dan makanan, negara telah menunjuk Badan POM RI [19]. Pengawasan di Sumatera

\section{Article history}

Received: 01 Jan 2020 Accepted: 16 Juni 2021 Published: 05 Agust 2020

Access this article

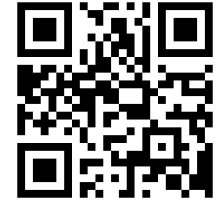


Barat dilakukan oleh BBPOM di Padang [20]. Penelitian ini bertujuan untuk mengkaji sejauh mana kinerja pengawasan obat keras di Sumatera Barat yang dilaksanakan oleh BBPOM di Padang sesuai dengan peraturan yang berlaku.

\section{Metode Penelitian}

\section{Rancangan Penelitian}

Penelitian bersifat evaluatif dengan pendekatan triangulasi [21,22]. Data kualitatif berasal dari hasil kuesioner dan hasil wawancara terstruktur. Data kuantitatif berasal dari laporan tahunan [23-25] dan laporan kinerja BBPOM di Padang [26-28], BBPOM di Jayapura [29-31] dan Badan POM RI tahun 2016-2018 [32-34].

\section{Populasi dan Sampel}

Populasi penelitian ini adalah masyarakat Sumatera Barat. Sampel yang digunakan adalah responden kuesioner yang berjumlah 70 orang yang berasal dari 7 kabupaten/ kota di Sumatera Barat. Sedang responden wawancara terstruktur berjumlah 10 orang yang berasal dari pejabat struktural BBPOM di Padang dan Jayapura.

\section{Instrumen}

Instrumen pada penelitian ini adalah kuesioner dan wawancara terstruktur. Kuesioner terdiri dari 5 jenis kuesioner yang diperuntukkan untuk responden pengelola apotik, tenaga kesehatan, tokoh masyarakat, pemilik swalayan dan pemilik toko obat berizin (TOB). Wawancara terstruktur terdiri dari 5 jenis kuesioner yang diperuntukkan untuk responden Kepala Balai, bidang pemeriksaan, bidang penindakan, bidang infokom dan bidang pengujian.

\section{Analisis Data}

Kuesioner divalidasi dengan parameter korelabilitas dan reliabilitas dengan persamaan Cronbach [35]. Hasil kuesioner, wawancara terstruktur, data laporan tahunan dan laporan kinerja dianalisa dengan pendekatan triangulasi $[21,22]$.

\section{Hasil dan Diskusi}

Sebanyak 5 jenis kuesioner tertutup divalidasi dengan nilai reliabilitas $0.8427 ; 0.8507 ; 0.7493 ; 0.7399$ dan 0.8272 yang lebih besar daripada $\mathrm{r}$ table $(\mathrm{df}=12, \alpha=0.05)$ yaitu 0.5324 sehingga semua instrument dapat digunakan.

Karakteristik responden kuesioner dibagi berdasarkan sebaran kabupaten/ kota dimana sebaran merata di 7 kab/ kota sebanyak $14.3 \%$, sebaran jenjang pendidikan dengan
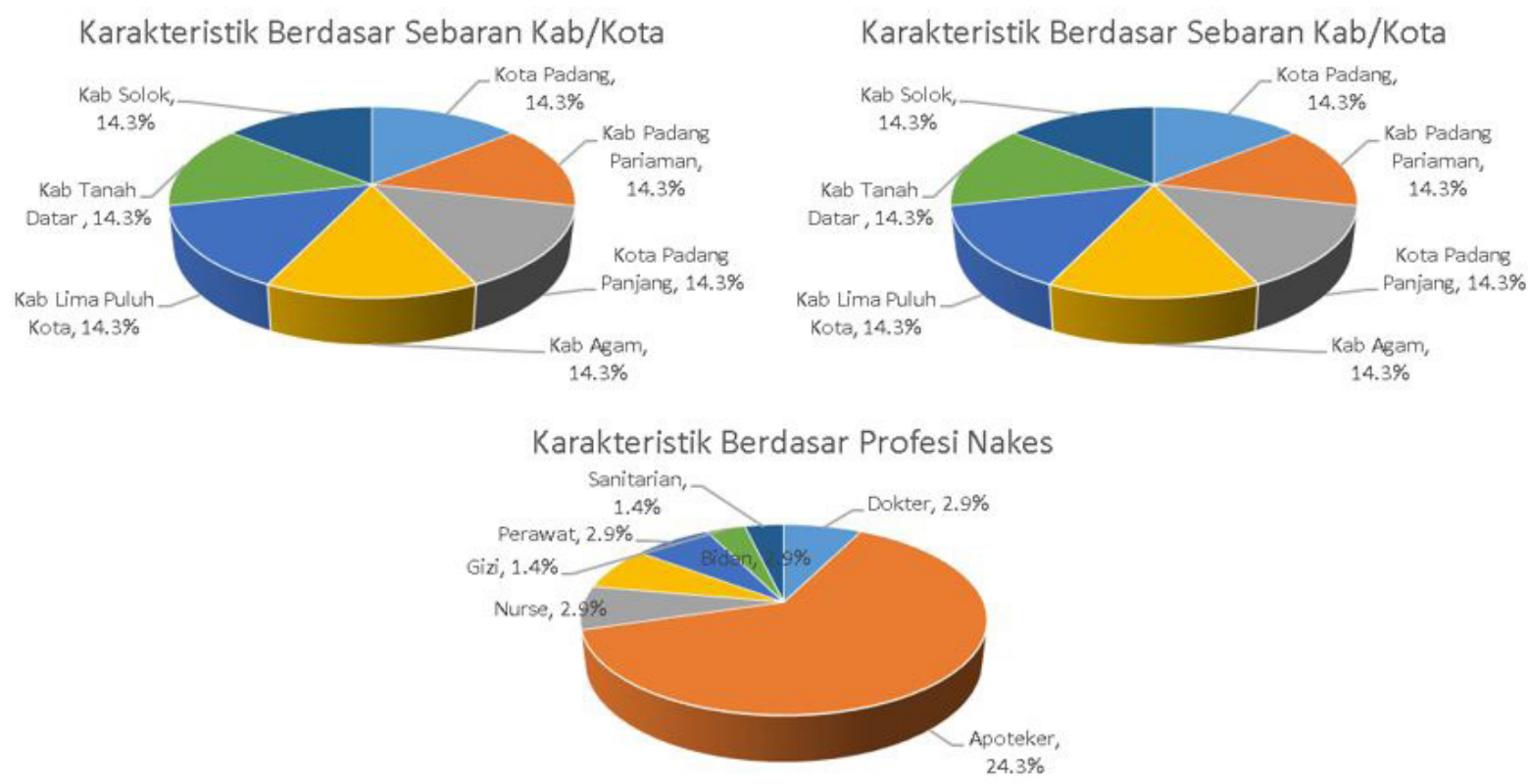

Gambar 1. Karakteristik responden kuesioner tertutup berdasar sebaran kab/kota, pendidikan dan profesi tenaga kesehatan 


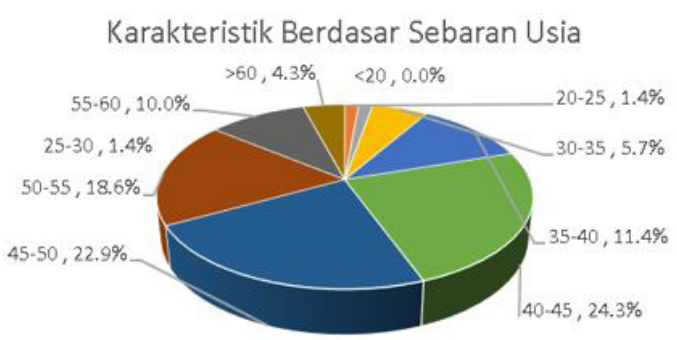

Karakteristik Berdasar Pengalaman Kerja

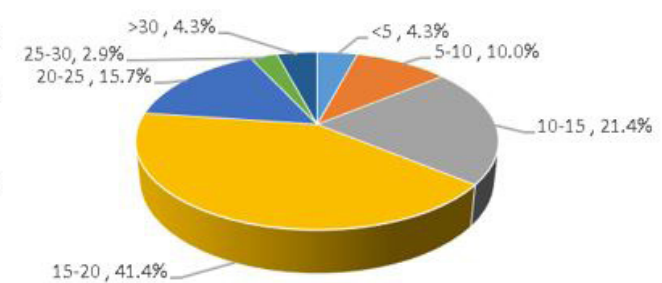

Karakteristik Berdasar Jenis Kelamin

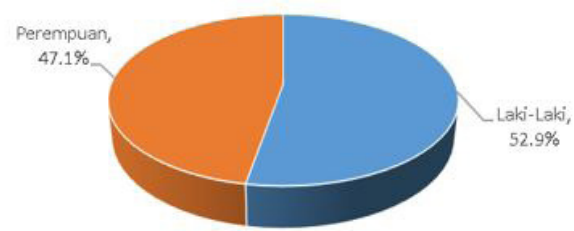

Gambar 2. Karakteristik responden kuesioner tertutup berdasar sebaran usia, pengalaman kerja dan jenis kelamin

pendidikan S1-profesi tertinggi sebesar 28.6\% dan sebaran profesi tenaga kesehatan dengan profesi apoteker tertinggi sebesar 24.3\% (Gambar 1). Sedangkan sebaran rentang usia dengan rentang 40-45 tahun terbanyak sebesar 24.3\%, sebaran pengalaman kerja dengan masa 15-20 tahun terbanyak sebesar $41.1 \%$ dan sebaran jenis kelamin yang berimbang yaitu $52.9 \%$ laki-laki dan $47.1 \%$ perempuan (Gambar 2).

Sedang karakteristik responden wawancara terstruktur dibagi berdasarkan bidang keahlian dengan sebaran merata sebesar $20.0 \%$ di 5 bidang, sebaran pendidikan dengan S1-profesi terbanyak sebesar $50.0 \%$ serta sebaran masa pengalaman kerja masa 25-30 tahun terbanyak sebesar $60.0 \%$ (Gambar 3).

Indeks kepatuhan pelaku usaha BBPOM di Padang mengalami penurunan di tahun 2016 dibanding 2015 lalu mengalami peningkatan di tahun 2017 dengan nilai 73.87; 64.71 dan 69.12 yang lebih tinggi dibanding ratarata nasional dan BBPOM di Jayapura (Gambar 4). Pada indeks survei kepuasan masyarakat terjadi peningkatan pada tahun 2018 dan 2019 sebesar 78.28 dan 87.77 bila dibanding dengan rata-rata nasional dan BBPOM di Jayapura (Gambar 5). Indeks kepatuhan pelaku usaha dan indeks kepuasan masyarakat di Sumatera Barat lebih tinggi
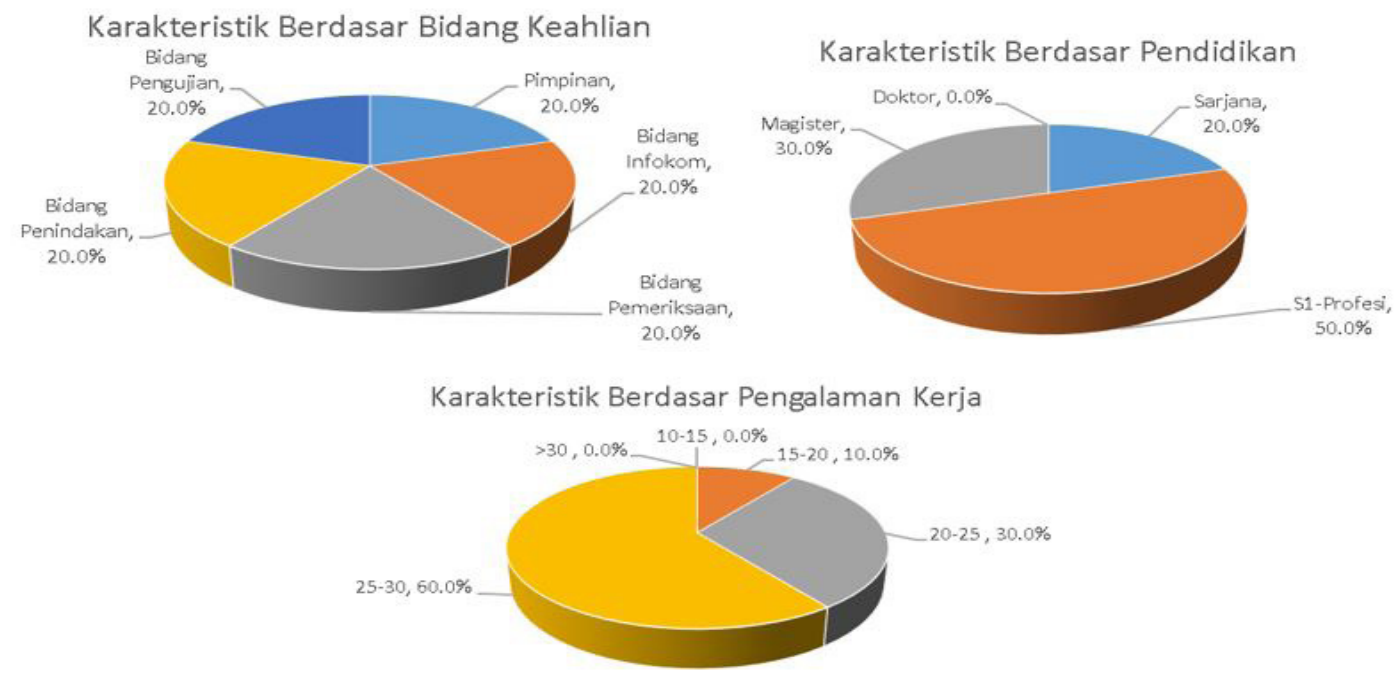

Gambar 3. Karakteristik responden kuesioner terbuka berdasar bidang keahlian, pendidikan dan pengalaman kerja 


\section{Survei Kepuasan Masyarakat}

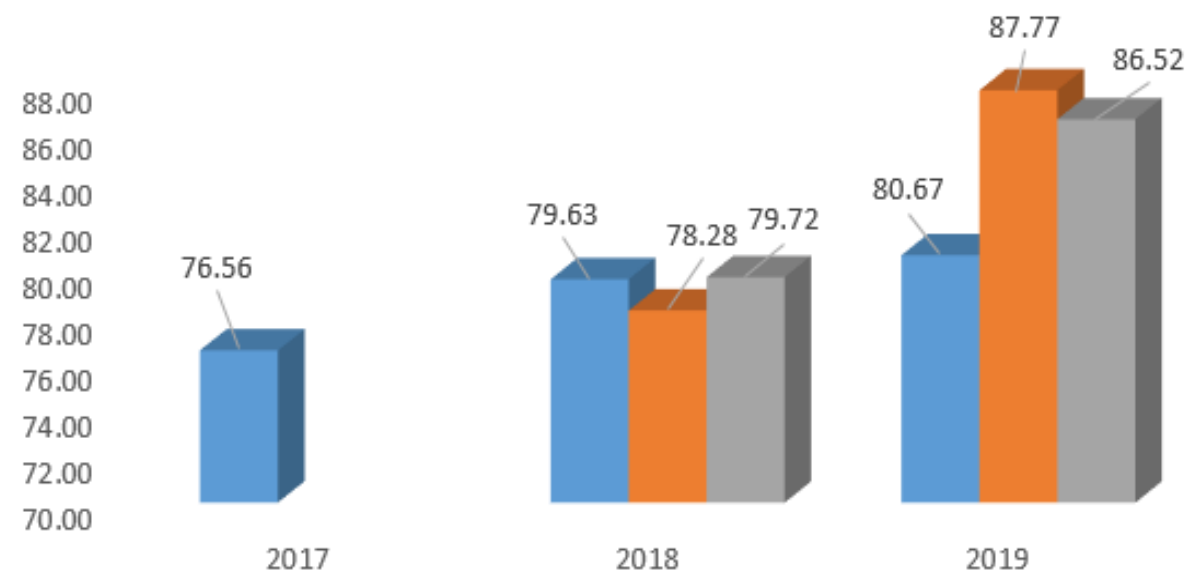

Gambar 4. Perbandingan tingkat survei kepuasan masyarakat (skala 100)

dibanding dengan rata-rata nasional. Hal ini menunjukkan kinerja positif BBPOM di Padang.

Pada hasil pengawasan obat keras di sarana Toko Obat Berizin (TOB) di Sumatera Barat terjadi peningkatan pada tahun 2016-2018 sebesar 24\%; 45; 49\% yang lebih tinggi bila dibanding di Papua (Gambar 6). Sementara hasil pengawasan obat keras di swalayan di Sumatera Barat mengalami penurunan dimana pada tahun 20162018 sebesar 9\%; 9\%; 8\% juga lebih tinggi bila dibanding di Papua (Gambar 7). Capaian peningkatan pengawasan BBPOM di Padang pada tahun 2018 sebesar 121.57\%
[26]. Hal ini disebabkan karena tingkat kepatuhan pemilik swalayan lebih tinggi dibanding pemilik TOB.

Tingkat keberhasilan penegakan hukum di Sumatera Barat mengalami peningkatan pada tahun 2017 dibanding 2016 lalu penurunan pada tahun 2018 sebesar 33.3\%; $70.0 \%$ dan $18.2 \%$ yang juga lebih tinggi dibanding di Papua (Gambar 8). Capaian peningkatan penyidikan tindak pidana obat dan makanan pada tahun 2018 sebesar $111.12 \%$. Hal ini disebabkan karena adanya perubahan trend pelanggaran dimana pada tahun 2018 trend pelanggaran bergeser dari obat keras ke kosmetika online ilegal.

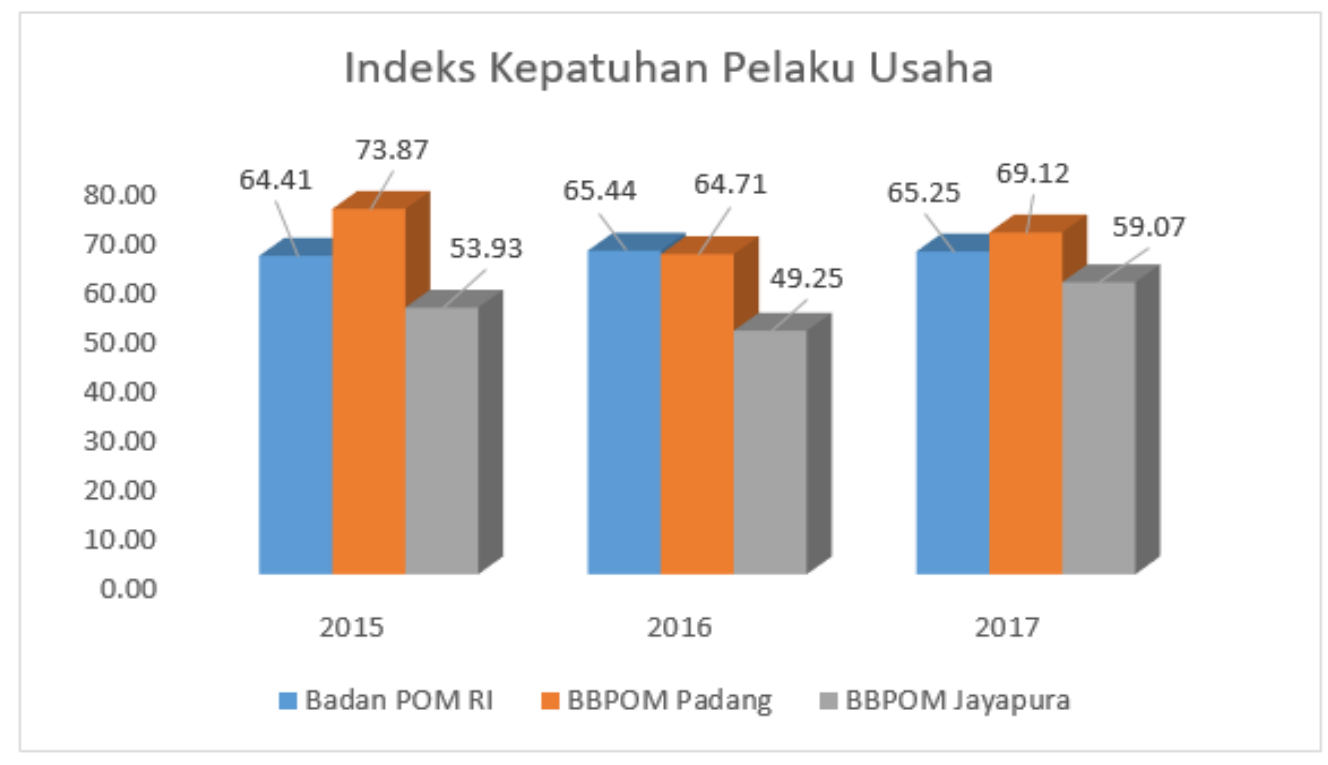

Gambar 5. Perbandingan tingkat indeks kepatuhan pelaku usaha (skala 100) 


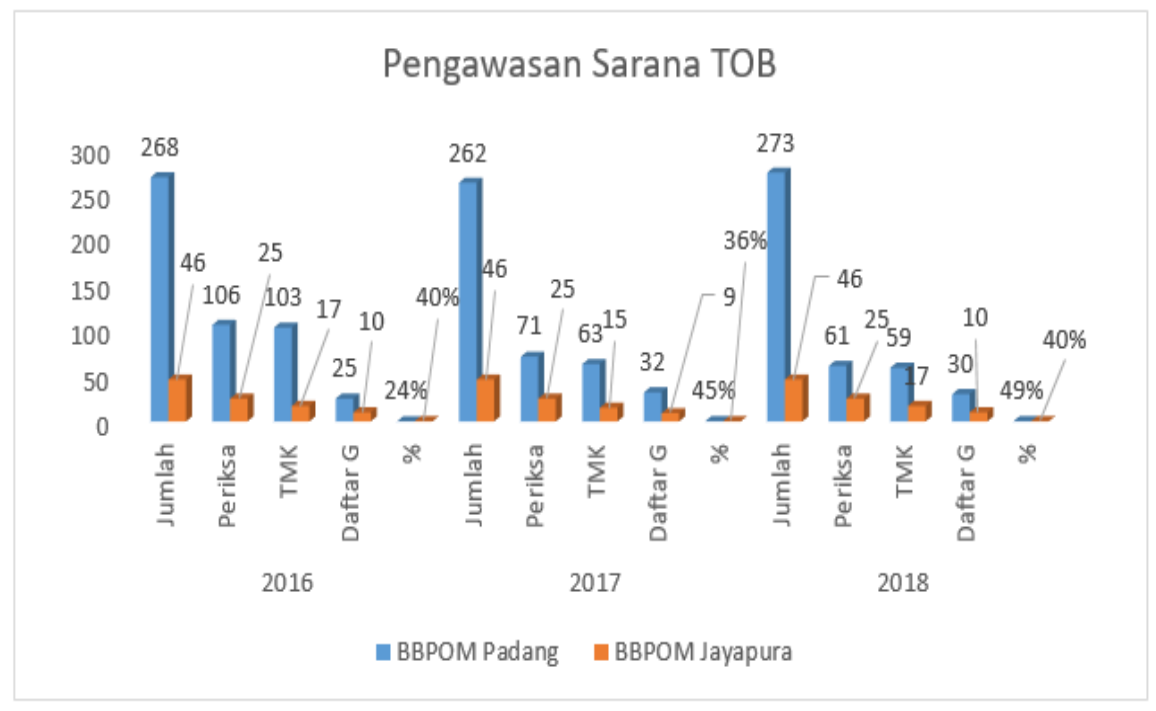

Gambar 6. Hasil pengawasan sarana TOB

Sementara tingkat keberhasilan pemberdayaan masyarakat melalui program penyuluhan, pameran, pengaduan dan sosialisasi di media elektronik/ media sosial mengalami peningkatan pada tahun 2017 dibanding 2016 lalu penurunan pada tahun 2018 sebesar 660; 714; 638 peserta (Gambar 9) dengan indeks pemberdayaan masyarakat sebesar $94.11 \%$ [26].

Kinerja pengawasan BBPOM di Padang diukur berdasarkan 3 sasaran strategis pada perjanjian kinerja tahun 2018 dengan capaian sasaran strategis: penguatan sistem pengawasan obat dan makanan (105.84\%), capaian peningkatan kemandirian pelaku usaha, kemitraan dengan pemangku kepentingan dan partisipasi masyarakat
(94.11\%) dan capaian peningkatan kualitas kapasitas kelembagaan BBPOM di Padang (88.93\%) [26].

Dari hasil analisa data kuesioner, wawancara terstruktur dan laporan tahunan/kinerja BBPOM dengan pendekatan triangulasi, profil kinerja pengawasan obat keras BBPOM di Padang mengalami trend peningkatan sesuai dengan data antara data kuantitatif (laporan tahunan), hasil wawancara dan hasil kuesioner [21,22].

Sementara tingkat keberhasilan penegakan hukum (Gambar 8) adanya perbedaan antara pengakuan dari pemilik TOB dan swalayan sebagai responden dengan data laporan tahunan dan hasil wawancara kepala bidang penindakan BBPOM di Padang. Hal ini disebabkan karena

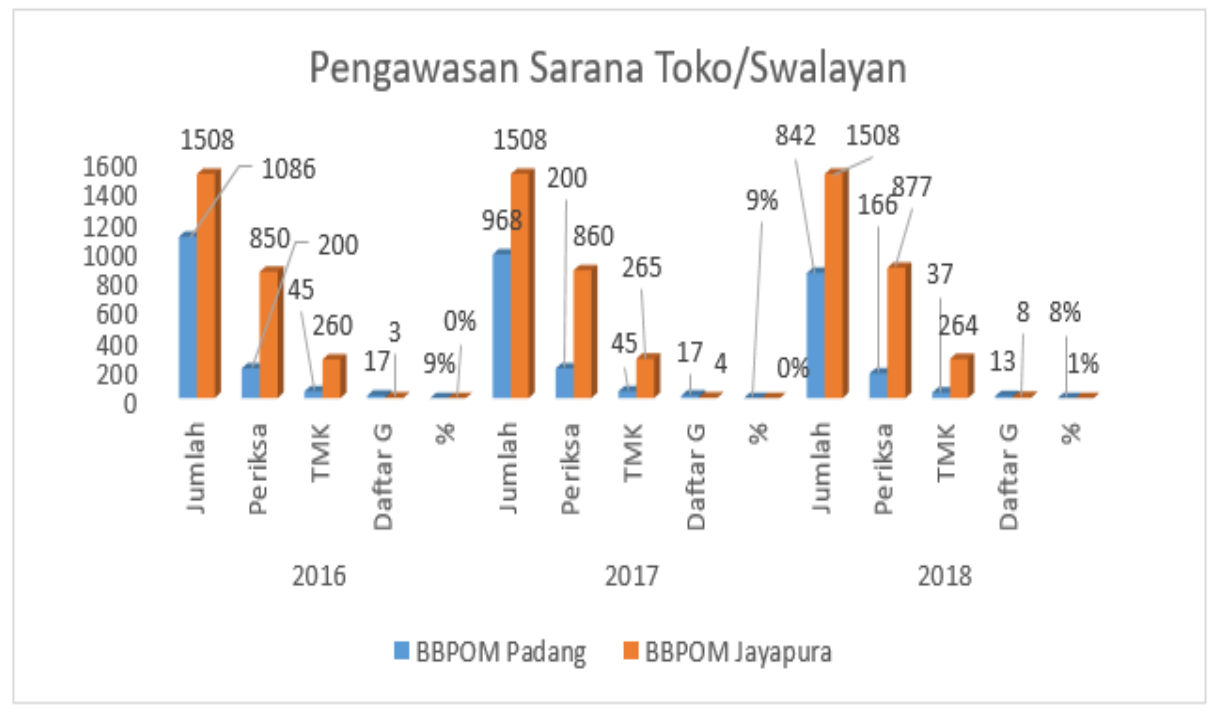

Gambar 7. Hasil pengawasan sarana swalayan 


\section{Penegakan Hukum}

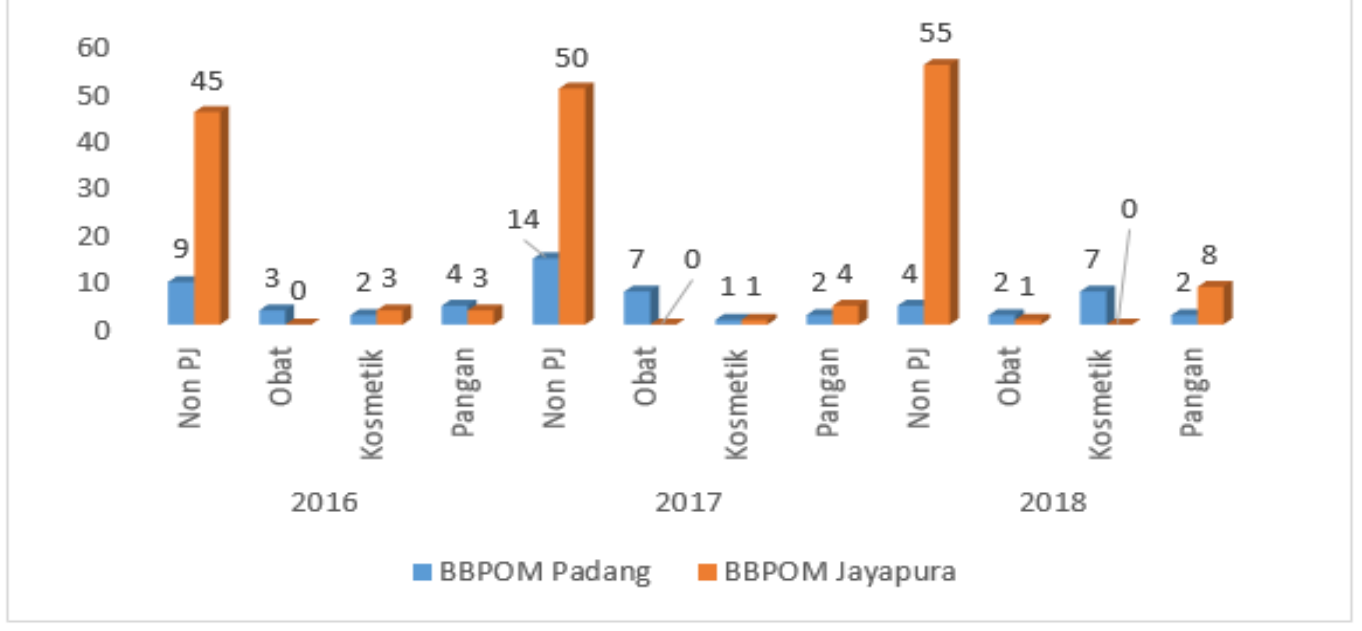

Gambar 8. Perbandingan penegakan hukum

temuan obat keras di TOB (Gambar 6) dan swalayan (Gambar 7) pada data kuantitatif ditindaklanjuti dengan sanksi administratif. Perbedaan ini dapat memberikan keakuratan data kualitatif dari sudut pandang yang berbeda [21,22].

Pada tingkat keberhasilan pemberdayaan masyarakat/ pelaku usaha, data antara laporan tahunan, wawancara dan hasil kuesioner memberikan kesamaan. Adanya peningkatan pengetahuan dari pelaku usaha (Gambar 4), peningkatan pemberdayaan konsumen (Gambar 9) dan peningkatan pengetahuan pemilik TOB dan swalayan bahwa obat keras dilarang dijual di sarana tersebut termasuk sangat tinggi sebesar $100.0 \%$ dan $92.9 \%$. Capaian peningkatan pemberdayaan masyarakat sebesar $94.11 \%$ [26].

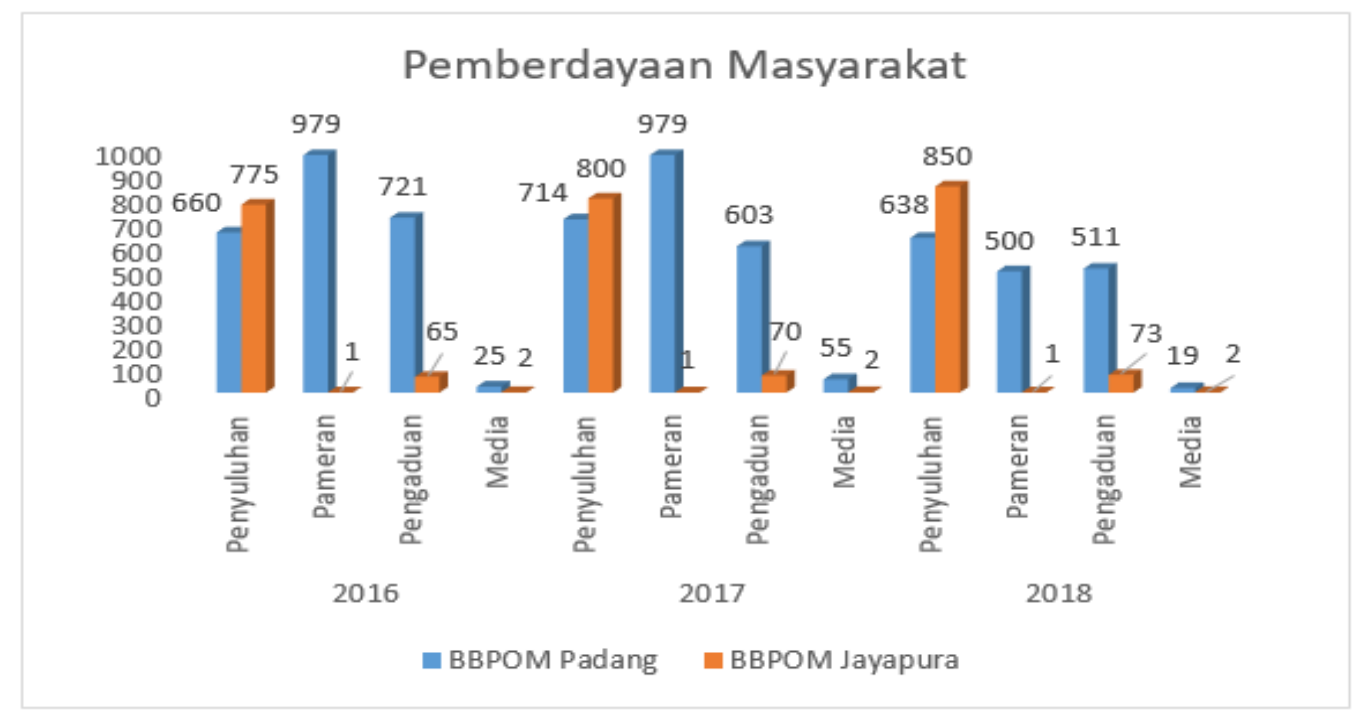

Gambar 9. Perbandingan pemberdayaan masyarakat 


\section{Kesimpulan}

Kinerja pengawasan obat dan makanan di Sumatera Barat oleh BBPOM di Padang dengan capaian peningkatan pengawasan (121.57\%), pemberdayaan masyarakat (94.11\%), penegakan hukum $(111.12 \%)$ dan sinergitas dengan stakeholder terkait (94.11\%). Kinerja masih harus terus dioptimalkan sehingga dapat menurunkan peredaran obat keras di sarana tidak berwenang baik melalui sisi supply, demand, law enforcement hingga sinergitas stakeholder terkait.

\section{Ucapan Terima Kasih}

Ucapan terima kasih kepada Kepala BBPOM di Padang dan Kepala BBPOM di Jayapura yang telah menyediakan data kuesioner terbuka dan laporan tahunan.

\section{Referensi}

[1]. BPOM, 2016. Laporan Tahunan BPOM RI Tahun 2015. Jakarta: Badan POM RI; 2015

[2]. Putra DA, Pengawasan Penjualan Obat Keras oleh Badan Pengawas Obat dan Makanan Pekanbaru Berdasarkan Undang-Undang No 36 Tahun 2009 Tentang Kesehatan. JOM Fakultas Hukum. 2014; 1(2):115

[3]. Lall SB, Paul R, Measure to Reduce Non-Medical Use of Prescription Drugs in South Asia. Chapter XII. 2001; 205-215

[4]. UU, Undang-Undang Kesehatan No 36. UU. Jakarta: Sekretariat Negara RI, 2009

[5]. Kurniawati M, Pengawasan Terhadap Pelayanan Obat Keras Tanpa Resep Dokter di Apotek oleh Dinas Kesehatan dan Balai Besar Pengawas Obat dan Makanan di Yogyakarta. Tesis. Yogyakarta: Universitas Gadjah Mada, 2013

[6]. WHO, The Pursuit of Responsible Use of Medicines: Sharing and Learning from Country Experiences [internet]. 2012 [cited 3 July 2018]. Available from http://www.who.int/medicines/areas/rational use/en

[7]. Menkes, Keputusan Menteri Kesehatan Republik Indonesia Nomor 189/Menkes/SK/III/2006 tentang Kebijakan Obat Nasional, Jakarta: Kementerian Kesehatan, 2006

[8]. Menkes, Keputusan Menteri Kesehatan Nomor 02396/A/SK/ VIII/1986 tentang Tanda Khusus Obat Keras Daftar G, Jakarta: Kementerian Kesehatan, 1986

[9]. Menkes, Keputusan Menteri Kesehatan Nomor 2380/A/SK/VI/1983 tentang Tanda Khusus Untuk Obat Bebas dan Obat Bebas Terbatas, Jakarta: Kementerian Kesehatan, 1983

[10]. Menkes, Peraturan Menteri Kesehatan Republik Indonesia Nomor 3 Tahun 2017 tentang Perubahan Penggolongan Psikotropika, Jakarta: Kementerian Kesehatan, 2017

[11]. Nita A., Urgensi Pembentukan Regulasi Penjualan Obat Melalui Media Online. Jurnal Legislasi Indonesia. 2018. Vol 15(1): 37-48

[12]. Asiska P.D., Isna W., Denia P., May V., Sosialisasi Gerakan Masyarakat Cerdas Menggunakan Obat di Desa Kumain Kecamatan Tandun Kabupaten Rokan Hulu. Jurnal Pengabdian Masyarakat Multidisplin. 2019. Vol 2 (2):132:137
[13]. Evita A., Analisis Penanggulangan Peredaran Obat Keras dan Obat Tertentu Melalui Media Online. Indonesian Private Law Review. 2020. Vol 1(2): 65-76

[14]. Rokhman M.R., Mentari W., Satibi, Ria F.F., Naimatul M., Yenda A.P. Penyerahan Obat Keras Tanpa Resep di Apotek. Jurnal Manajemen dan Pelayanan Farmasi. 2017. Vol 7(3): 115-124

[15]. Andi S., Perlindungan Konsumen Terhadap Penyaluran Obat Keras Daftar G oleh Badan POM di Makasar. Jurisprudentie. 2017. Vol 4(2): 24-36

[16]. Yulia P., Kristin C.S., Hubungan Pengetahuan Pasien Tentang Obat Keras Terhadap Pembelian dan Kepatuhan Pasien Minum Obat Antibiotika Tanpa Resep Dokter di Apotek Kabupaten Kudus. Cendekia Journal of Pharmacy. 2019. Vol 3(2): 74-84

[17]. Sumartini D., Medikolegal Pengobatan Untuk Diri Sendir (Swamedikasi) Sebagai Upaya Menyembuhkan Penyakit. Hukum dan Dinamika Masyarakat. 2017. Vol 15(1): 86-93

[18]. Ana H., Hafizah D., Murtyk D.P., Tingkat Pengetahuan Penggunaan Obat Bebas dan Obat Bebas Terbatas Untuk Swamedikasi pada Mayarakat RW 8 Morobangun Jogotirto Berbah Sleman Yogyakarta. Jurnal IImiah Manuntung. 2017. 3(2): 139-149

[19]. Keppres, Keputusan Presiden No 173. Kedudukan, Tugas, Fungsi, Wewenang, Susunan Organisasi dan Tata Kerja Lembaga Pemerintah Non Departemen. Jakarta: Sekretariat Negara, 2000

[20]. BPOM, Peraturan Kepala Badan POM RI No 12. Organisasi dan Tata Kerja Unit Pelaksana Teknis di Lingkungan Badan POM. Jakarta: Berita Negara, 2018

[21]. Bachri BS, Meyakinkan Validitas Data Melalui Triangulasi Pada Penelitian Kualitatif. Jurnal Teknologi Pendidikan. 2010, Vol 10(1) 46-62

[22]. Rahardjo M, Triangulasi dalam Penelitian Kualitatif. Media Informasi and Kebijakan Kampus. 2010:1-5

[23]. BBPOM, Laporan Tahunan Balai Besar POM di Padang, Padang: BBPOM, 2019

[24]. BBPOM, Laporan Tahunan Balai Besar POM di Padang, Padang: BBPOM, 2018

[25]. BBPOM, Laporan Tahunan Balai Besar POM di Padang, Padang BBPOM, 2017

[26]. BBPOM, Laporan Kinerja Balai Besar POM di Padang, Padang: BBPOM, 2019

[27]. BBPOM, Laporan Kinerja Balai Besar POM di Padang, Padang BBPOM, 2018

[28]. BBPOM, Laporan Kinerja Balai Besar POM di Padang, Padang: BBPOM, 2017

[29]. BBPOM, Laporan Tahunan Balai Besar POM di Jayapura, Jayapura: BBPOM, 2019

[30]. BBPOM, Laporan Tahunan Balai Besar POM di Jayapura, Jayapura: BBPOM, 2018

[31]. BBPOM, Laporan Tahunan Balai Besar POM di Jayapura, Jayapura: BBPOM, 2017

[32]. BPOM, Laporan Tahunan BPOM RI Tahun 2018. Jakarta: Badan POM $\mathrm{RI}, 2019$

[33]. BPOM, Laporan Tahunan BPOM RI Tahun 2017. Jakarta: Badan POM $\mathrm{RI}, 2018$

[34]. BPOM, Laporan Tahunan BPOM RI Tahun 2016. Jakarta: Badan POM $\mathrm{RI}, 2017$

[35]. Febrianawaty Y., Uji Validitas dan Reliabilitas Instrumen Penelitian Kuantitatif. Jurnal Tarbiyah. 2018. Vol 7(1): 17-23

[36]. Salma H., Lailatussaadah, Validitas dan Reliabilitas Instrumen Pengetahuan Pembelajaran Aktif Kreatif dan Menyenangkan Menggunakan Model Rasch. Jurnal IImiah Didaktika. 2016. Vol 16(2): 169-179

[37]. Yulyanti F., Fahmi M., Validitas dan Reliabilitas Konstruk Pengukuran Perpustakaan Ideal Berbasis Pemakai dengan Pendekatan Libqual. Jurnal Ekonomi Bisnis dan Kewirausahaan. 2017. Vol 6(2): 161-174. 